\title{
ボイドスラブを空調用ダクトとして利用する場合の 熱性能の数值解析
}

\author{
A NUMERICAL ANALYSIS OF THERMAL PERFORMANCE \\ OF VOID SLABS USED AS AN AIR-CONDITIONING DUCT
}

\author{
小原聡司*, 赤坂 裕** \\ Satoshi OBARA and Hiroshi AKASAKA
}

\begin{abstract}
Unsteady state thermal behavior of void slabs used as an air-conditioning duct was numerically analyzed with FEM computer program. Non-insulated void slab and eight types of insulated void slab were simulated. The following results were obtained:

(1) When a void slab is used as a floor, inside surface of the void should be insulated. If the thickness of insulation exceeds $30 \mathrm{~mm}$, the temperature difference on the floor surface becomes less than 1 degree $\mathrm{C}$ and the surface condensation during cooling period can almost be avoided.

(2) When a void slab is used as a roof, inside surface of the void as well as exterior surface of the roof should be insulated. The recommended thickness of insulation is more than $30 \mathrm{~mm}$ for inside surface of the void and $100 \mathrm{~mm}$ for exterior surface of the roof, respectively.
\end{abstract}

\section{Keywords: void slab, finite element method(FEM), air-conditioning duct, simulation}

\author{
ボイドスラフ，有限要素法，空調用ダクト，数値計算
}

1.はじめに

本研究で扱うボイドスラブとはコンクリート躯体内部 に水平な冈筒状の中空部(ボイド)を並列に配置したスラ

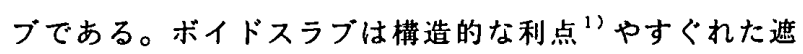
音性能 ${ }^{2) 、 3)}$ により, 事務所ビルや集合住宅で広く使用 されている。

このボイドスラブを空調用ダクトとして利用すれば， 水平ダクトの施工が不要になること, ダクトスペースが 節約できること等の点で有利である。しかし一方ではボ イドの空気流とボイド内表面との間に熱授受が生して供 給空気の温度が変化し, 空調に有効利用できる熱量が減 少する等，熱的な面では不利になる可能性もある。この ような熱収支にはボイドスラブの断熱法が大いに影響す る。したがってボイドを空調ダクトとして利用するには， ボイドスラブの伝熱特性をその断熱法と関連づけて明ら かにしておく必要がある。

本研究ではボイドスラブに有限要素法(FEM)による 2
次元の非定常伝熱解析を適用し，供給空気流と直交する 平面内における温度分布とボイド内の空気温度を求め, これを流れ方向に繰り返すことによってボイドスラブの 非定常伝熱を 3 次元的に解析する方法を開発した。ボイ ドの熱伝達に関しては，ボイド内気流速度による中空部 の対流熱伝達率の変化とボイド内表面の相互放射の影幚 を考虑した。

次に上記の解析法を適用し，種々の断熱を施したボイ ドスラブを事務所ビルの最上階または中間階の空調ダク トとして用いる場合について, ボイドスラブ各部の温度 や熱流量を求める数值計算を行った。この計算において は現実的な送風量(流速)と送風温度を設定し，外気温・ 室温に関しては日周期変動を考虑した。また供給された 熱量のうち室の冷暖房に真に寄与する割合を表す係数を 定義し，各種ボイドスラブについての同係数の計算結果 に基つき，ボイドスラブの断熱方法について考察を加え た。さらに冷房時における中間階のスラブ表面について
* 都城工業高等専門学校建築学科 講師 $\cdot$ 工修

** 鹿児島大学工学部建築学科 教授・工博
Asst. Prof., Dept. of Architecture, Miyakonojo National College of Technology, M. Eng.

Prof., Dept. of Architecture, Faculty of Engineering, Kagoshima University, Dr. Eng. 
は，結整発生の可能性及び断熱による結露危険性の㪕隇 効果も検討した。以上の内容について報告する。

\section{2. 徽值解析の手法}

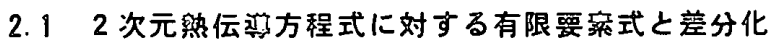
式(1)は固体内部の 2 次元熱伝贈方程式を示す。

$$
\rho \mathrm{c} \frac{\partial \theta}{\partial \mathrm{t}}=\lambda\left(\frac{\partial^{2} \theta}{\partial \mathrm{x}^{2}}+\frac{\partial^{2} \theta}{\partial \mathrm{y}^{2}}\right)
$$

ここで,

$$
\begin{array}{ll}
\rho: \text { 密度, }\left[\mathrm{kgf} / \mathrm{m}^{3}\right] & \mathrm{c}: \text { 比熱, }[\mathrm{J} / \mathrm{kgf} \circ \mathrm{K}] \\
\theta: \text { 温度, }\left[{ }^{\circ} \mathrm{C}\right] & \lambda: \text { 熱伝斯率, }[\mathrm{H} / \mathrm{m} \circ \mathrm{K}]
\end{array}
$$

式(1)に対してGalerkin法を適用し，境界条件も含めて 空間的に離散化を行った有限要素式の一般的表現は次式 となる

$$
[\mathrm{K}]\{\phi\}+[\mathrm{C}]\left\{\frac{\partial \phi}{\partial \mathrm{t}}\right\}=\{\mathrm{F}\}
$$

ここで,

$\begin{array}{ll}{[\mathrm{K}]: \text { 熱伝卙マトリタクス }} & \{\phi\}: \text { 節点温度ベ外ル } \\ {[\mathrm{C}]: \text { 熱容量マトリクス }} & \{\mathrm{F}\}: \text { 熱流束ベクトル }\end{array}$ 式(2)に対し，Crank-Nicolson形の差分化により，時間 的な離散化を行った場合の一般式は次式となる。

$$
\begin{aligned}
& \left(\frac{1}{2}[\mathrm{~K}]+\frac{1}{\Delta \mathrm{t}}[\mathrm{C}]\right)\{\phi(\mathrm{t})\} \\
& =\left(-\frac{1}{2}[\mathrm{~K}]+\frac{1}{\Delta \mathrm{t}}[\mathrm{C}]\right)\{\phi(\mathrm{t}-\Delta \mathrm{t})\}+\{\mathrm{F}\}
\end{aligned}
$$

ここで扱うボイドスラブに関しては，全三角形要素の節 点とボイドの空気温度が未知数であり，\{申\}はこれらの 温度を要素とするべクトルである。[C]は熱伝達面の有 無に影㸷されないが， $[\mathrm{K}] と\{F\}$ は熱伝達面の有無，熱 伝達面間の相互放射を考虑するか否か等によって異なる。 ボイドスラブに対応した有限要素式や差分化した式につ いては既発表の文献[1], [2]にまとめてある。

\section{2 ボイドスラブの断面形状のそデル化}

図 1 は円形断面のボイドを有するスラブの，供給空気 の流れ方向に直交する断面を示す。スラブ本体は厚さ 4C0mmのコンクリートであり, 内部に厚さ0. $5 \mathrm{~mm}$ スチー
ル管(ワインディング・パイプ)で囲わ机た円筒状中空部 (ボイド)を有している。ボイドの配置間隔はスラブ厚と 同し400mmである。図 2 は三角形要素による分割例を示 す。円筒状ボイドは図に示すような正 8 角柱(形)で近似 した。断熱境界面はボイドの配置間隔と等しくとっだ。 ボイド部の形状や要素分割形状については分割の粗細が 解に影することが予想される。そこでFEM沉用解析り フトウェア ${ }^{5)}$ の要素分割機能を用いた紐かな要素分割 (以後細分割モテルと呼ふ）と，本研究で用いた分割モテ ル(以後組分割モテルと呼ふ)を同一プログラムで計算し た。両モテルとも初期条件や境界条件は同一(スラブの 初期温度及び上下空間の温度 $0^{\circ} \mathrm{C}$, 対流熱伝達率上側 11.6 $\mathrm{H} / \mathrm{m}^{2} \circ \mathrm{K}$ ，下側 $7.0 \mathrm{H} / \mathrm{m}^{2} \circ \mathrm{K}$ ，ボイド表面 $\left.15.0 \mathrm{H} / \mathrm{m}^{2} \circ \mathrm{K}\right)$ とし， ボイド空気温を $10^{\circ} \mathrm{C}$ に励振させた場合の定常時の温度分 布を求めた。両モテルで共通の座標における温度分布を 図 4 に示す。ボイド表面温度は節点(7)で最大 $0.41^{\circ} \mathrm{C}$ 差 があるが，他は $0.05^{\circ} \mathrm{C}$ 未满である。また上下表面温度は $0.2^{\circ} \mathrm{C}$ (節点(3)程度の差である。このように細分割モテ ルと祖分割モデルの違いはわずかである。そこで祖分割 モテルを断面モデルとして採用した。なお実際のボイド スラブではコンクリートの打ち込み時にスチール管の位 置を保持するため，鉄筋やスペーサー等の金属材料を使 用するが(図 1 参照)，これらは 3 次元的に大きな間隔で 配置されるため熱的な影㸷は小さいと判断し，ここでは それらを省略したモデ化を行った。

2.3 ボイド空気温度の武出

\subsection{1 空铜棉止時のボイド空気温度}

図 3 に示すような 2 次元断面のボイド空気温度につい て，空調停止時には次式が成り立つ。

$v \rho \mathrm{c} \frac{\partial \theta_{\mathrm{a}}}{\partial \mathrm{t}}=\sum_{i=1}^{8} \alpha_{\mathrm{cni}} \frac{\ell_{\mathrm{i}-1}+\ell_{\mathrm{i}}}{2}\left(\theta_{\mathrm{i}}-\theta_{\mathrm{a}}\right) \cdots(4)$ ここで,

$\mathrm{v}$ :ボイドの断面稹, $\left[\mathrm{m}^{2}\right] \quad \theta_{\mathrm{i}}$ : 節点 $\mathrm{i} の$ 温度, $\left[{ }^{\circ} \mathrm{C}\right]$ $\alpha_{\mathrm{cn} \mathrm{i}}$ :節点 $\mathrm{i}$ の自然対流熱伝達率, $\left[\mathrm{g} / \mathrm{m}^{2} \circ \mathrm{K}\right]$

$\ell_{i}, \ell_{i-1}$ :円に近似させた正 8 角形の一辺の長さ, [m]

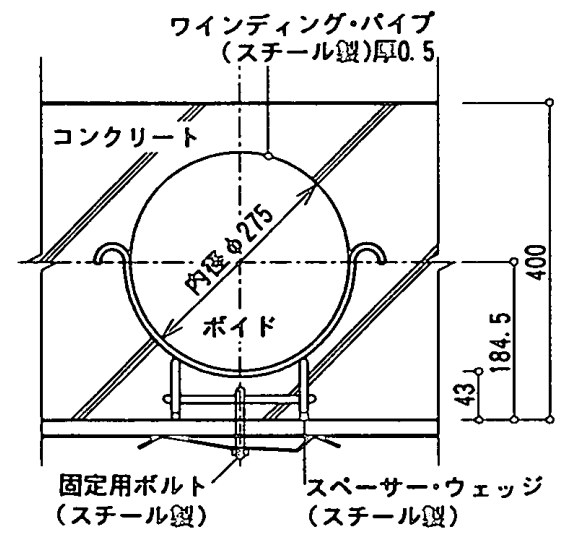

图 1 ボイドスラブの断面 些位 $[\mathrm{mm}]$

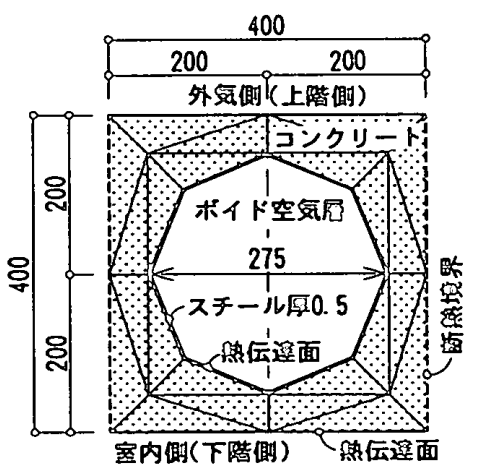

图 2 有限要焦によるボイドスラブ の分锂モデル例 置位 [mm]
円柱状ボイド部分を正 8 角形(性)に近似

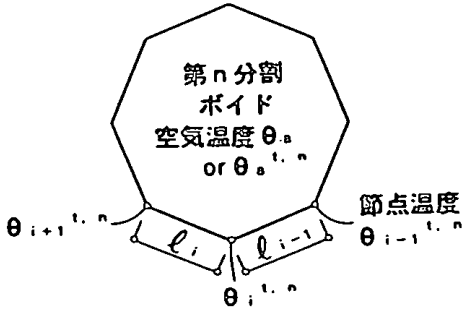

图 3 ボイド断面形状のモテル化 


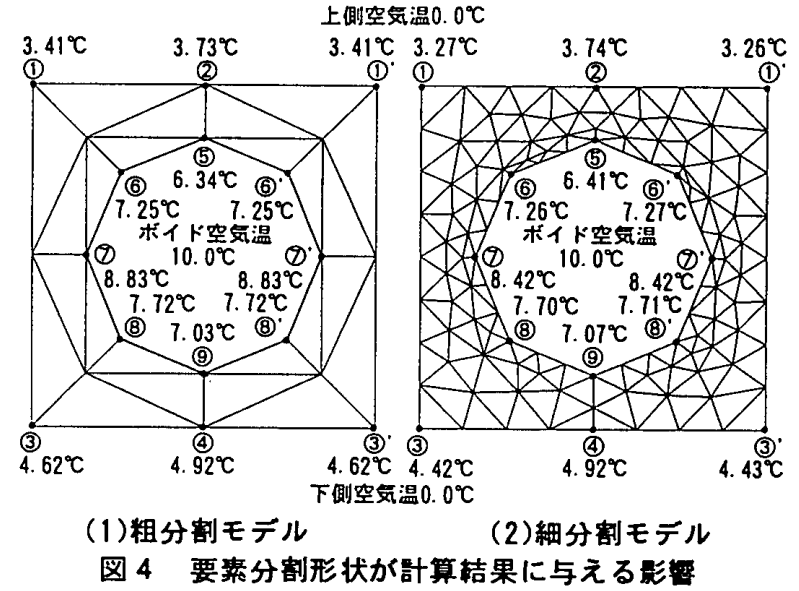

$\mathrm{i}$ :ボイド表面にある節点の番号 $(\mathrm{i}=1 \sim 8)$

$\mathrm{t}:$ 計算ステップの時間間隔, [s]

$\theta_{\mathrm{a}}:$ ボイド空気温度, $\left[{ }^{\circ} \mathrm{C}\right]$

式(4)に対し, Crank-Nicolson形の離散化を行うと, 式 (5)となる。

$$
\begin{aligned}
& -\sum_{i=1}^{8} \frac{\alpha_{c n i}\left(\ell_{i-1}+\ell_{i}\right)}{4} \theta_{i} \\
& \quad+\left\{\sum_{i=1}^{B} \frac{\alpha_{c n i}\left(\ell_{i-1}+\ell_{i}\right)}{4}+\frac{v \rho c}{\Delta t}\right\} \theta_{a}^{t} \\
& =\sum_{i=1}^{8} \frac{\alpha_{c n i}\left(\ell_{i-1}+\ell_{i}\right)}{4} \theta_{i}{ }^{t-1} \\
& \quad+\left\{-\sum_{i=1}^{8} \frac{\alpha_{c n i}\left(\ell_{i-1}+\ell_{i}\right)}{4}+\frac{v \rho c}{\Delta t}\right\} \theta_{a}{ }^{t-1} \cdots
\end{aligned}
$$

空調停止時には式(5)を式(3)に組み込んで, $\mathrm{t}-1$ 時に おけるボイドの空気温度 $\theta \mathrm{a}^{\mathrm{t}-1}$ 及び全部の節点の温度か ら， $\mathrm{t}$ 時におけるボイド空気温度及び全部の節点の温度 を求める。この計算を図 5 に示すボイドスラブの各断面 について行う。

\subsection{2 空調時のボイド空気温度}

空調時には図 5 のボイドへの空気供給口から吹出口ま での全長 $\mathrm{L}$ を分割間隔 $\Delta \mathrm{L} て ゙ N$ 分割したモデルを考え， 第 $\mathrm{n}-1$ 断面における節点の温度及びボイド空気温度を 用いて第 $\mathrm{n}$ 断面の各温度を求める。

$\mathrm{n}$ 分割区間におけるボイドの空気温度とボイド表面に は次の熱平衡式が成り立つ。

$\mathrm{q}_{0}=\mathrm{q}_{\mathrm{c}}+\mathrm{q}_{\mathrm{v}}$

$\mathrm{q} s[\mathrm{~J}]$ は $\Delta \mathrm{t}$ 時間内の $\theta \mathrm{s}$ の温度変化による空気の吸 熱量であり，次式で表される。

$\mathrm{q}_{\mathrm{a}}=\Delta \mathrm{L}$ v $\rho \mathrm{c} \Delta \theta_{\mathrm{a}}{ }^{\mathrm{n}}$

ここで,

$\Delta \mathrm{L}:$ 流れ方向の分割の間隔, $\Delta \mathrm{L}=\mathrm{L} / \mathrm{N},[\mathrm{m}]$

$\mathrm{L}$ :ボイド全長, $[\mathrm{m}] \mathrm{N}$ :流れ方向のボイド分割数 また $\mathrm{q} c[\mathrm{~J}]$ は $\mathrm{n}$ 分割区間における $\Delta \mathrm{t}$ 時間の対流熱伝達 量であり，次式で表される。

$$
\mathrm{q}_{\mathrm{c}}=\sum_{\mathrm{i}=1}^{8} \alpha_{\mathrm{cf} i} \Delta \mathrm{L} \frac{\ell_{\mathrm{i}-1}+\ell_{\mathrm{i}}}{2}\left(\theta_{\mathrm{i}^{\mathrm{n}}}-\theta_{\mathrm{a}}{ }^{\mathrm{n}}\right) \Delta \mathrm{t}
$$

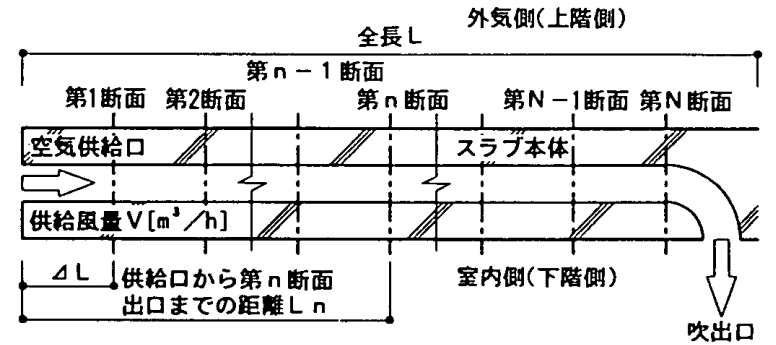

図 5 供給空気の流れ方向の断面

ここで,

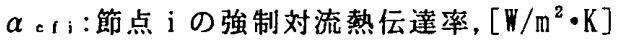

$\theta_{\mathrm{i}}{ }^{\mathrm{n}}$ :第 $\mathrm{n}$ 断面のボイド表面節点 $\mathrm{i}$ の温度, $\left[{ }^{\circ} \mathrm{C}\right]$

$\theta a{ }^{n}:$ 第 $\mathrm{n}$ 断面のボイド空気温度, $\left[{ }^{\circ} \mathrm{C}\right]$

$\mathrm{q}$ 。 $[\mathrm{J}]$ は $\mathrm{n}$ 分割区間における空気流れによる移動熱量で あり，次式で表される。

$\mathrm{q} v=v \mathrm{v} \rho \mathrm{c}\left(\theta_{\mathrm{a}}{ }^{\mathrm{n}-1}-\theta_{\mathrm{a}}{ }^{\mathrm{n}}\right) \Delta \mathrm{t}$ ここで,

$v:$ 空気の流速, [m/s]

$\theta \mathbf{a}^{\mathrm{n}-1}:$ 第 $\mathrm{n}-1$ 断面のボイド空気温度, $\left[{ }^{\circ} \mathrm{C}\right]$

$\sum_{i=1} \alpha_{c 1 i} \frac{\ell_{i-1}+\ell_{i}}{2}=\sum_{i} B_{i}$ とおくと, 式(6)は,

$\Delta \mathrm{L} v \rho \mathrm{c} \Delta \theta_{\mathrm{a}}{ }^{\mathrm{n}}=\sum_{\mathrm{i}} \mathrm{B}_{\mathrm{i}} \Delta \mathrm{L}\left(\theta_{\mathrm{i}}{ }^{\mathrm{n}}-\theta_{\mathrm{a}}{ }^{\mathrm{n}}\right) \Delta \mathrm{t}$

$$
+v \mathrm{v} \rho \mathrm{c}\left(\theta_{\mathrm{a}}^{\mathrm{n}-1}-\theta_{\mathrm{a}}{ }^{\mathrm{n}}\right) \Delta \mathrm{t}
$$

式(10)を知関する微分形式で表現すると，

$$
\begin{aligned}
\mathrm{v} \rho \mathrm{c} \frac{\partial \theta_{\mathrm{a}}}{\partial \mathrm{t}} & =\sum_{\mathrm{i}} \mathrm{B}_{\mathrm{i}}\left(\theta_{\mathrm{i}}{ }^{\mathrm{n}}-\theta_{\mathrm{a}}{ }^{\mathrm{n}}\right) \\
+ & \frac{U \mathrm{v} \rho \mathrm{c}}{\Delta \mathrm{L}}\left(\theta_{\mathrm{a}}{ }^{\mathrm{n}-1}-\theta_{\mathrm{a}}{ }^{\mathrm{n}}\right)
\end{aligned}
$$

これをCrank-Nicolson形に離散化すると，

$$
\begin{aligned}
& -\sum_{i} \frac{\mathrm{B}_{i}}{2} \theta_{i}{ }^{\mathrm{t}}{ }^{\mathrm{n}}+\left(\sum_{\mathrm{i}} \frac{\mathrm{B} i}{2}+\frac{\mathrm{v} \rho \mathrm{c}}{\Delta \mathrm{t}}+\frac{v \mathrm{v} \rho \mathrm{c}}{2 \Delta \mathrm{L}}\right) \theta_{\mathrm{a}}^{\mathrm{t}}{ }^{\mathrm{n}} \\
& =\sum_{\mathrm{i}} \frac{\mathrm{B}_{\mathrm{i}}}{2} \theta_{\mathrm{i}}^{\mathrm{t}-1, \mathrm{n}} \\
& \quad+\left(-\sum_{\mathrm{i}} \frac{\mathrm{B} \mathrm{i}}{2}+\frac{\mathrm{v} \rho \mathrm{c}}{\Delta \mathrm{t}}-\frac{v \mathrm{v} \rho \mathrm{c}}{2 \Delta \mathrm{L}}\right) \theta_{\mathrm{a}}{ }^{\mathrm{t}-1, \mathrm{n}} \\
& \quad+\frac{v \mathrm{v} \rho \mathrm{c}}{2 \Delta \mathrm{L}}\left(\theta_{\mathrm{a}}^{\mathrm{t} \cdot \mathrm{n}-1}+\theta_{\mathrm{a}}^{\mathrm{t}-1, \mathrm{n}-1}\right) \cdots \cdots
\end{aligned}
$$

ここで

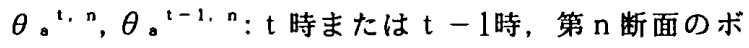

$$
\begin{aligned}
& \text { イド空気温度, }\left[{ }^{\circ} \mathrm{C}\right] \\
& \theta_{i}{ }^{t, n}, \theta_{i}{ }^{t-1, n}: t \text { 時または } \mathrm{t}-1 \text { 時, 第 } \mathrm{n} \text { 断面のボ } \\
& \text { イド表面節点温度, }\left[{ }^{\circ} \mathrm{C}\right]
\end{aligned}
$$

式 (12)を空調停止時の式(5)と比較すると, 左辺には,

$$
\frac{v \mathrm{~V} \rho \mathrm{C}}{2 \Delta \mathrm{L}} \theta_{\mathrm{a}} \mathrm{n}
$$

右辺には，

$$
\begin{aligned}
- & \frac{v \mathrm{~V} \rho \mathrm{c}}{2 \Delta \mathrm{L}} \theta_{a^{\mathrm{t}}-1 \cdot \mathrm{n}} \\
& \frac{v \mathrm{~V} \rho \mathrm{c}}{2 \Delta \mathrm{L}}\left(\theta_{a}^{\mathrm{t} \cdot \mathrm{n}-1}+\theta_{a^{\mathrm{t}-1 \cdot n-1}}\right)
\end{aligned}
$$

が追加されている。いずれも空気流れによる移動熱量の 


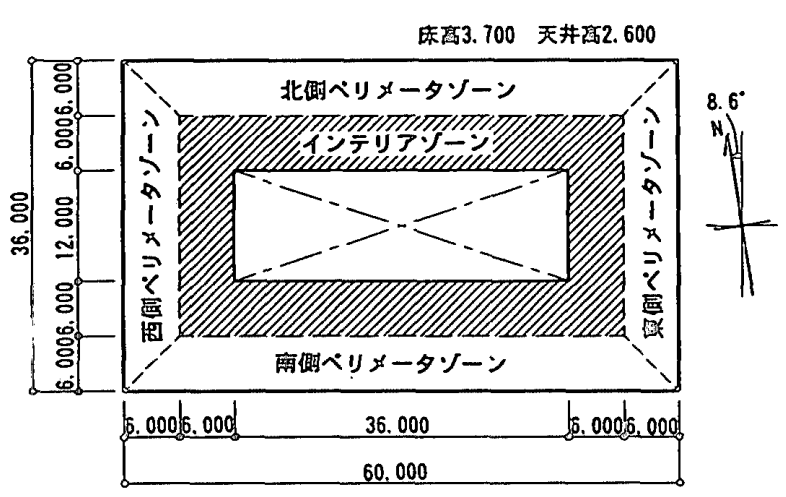

图 6

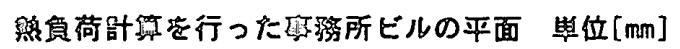

項である。

空調時には式(12)を式(3)に組み込んで， $\mathrm{t}$ 時におけ るボイドの空気温度と全部の節点の温度を第1断面から 第 N断面方向に逐次求めることができる。

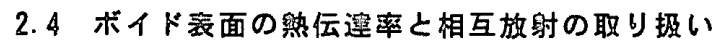

ボイド表面節点に総合熱伝達率を与える場合と, 対流 ・放射熱伝達率を分離し各面間の相互放射を考感する場

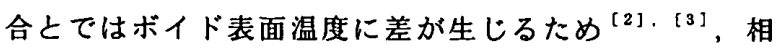
互放射の影急を虑することにする。ボイド表面節点 $\mathrm{i}$ からの放射熱伝達量 q : は式(16)で求められる。

$$
\mathrm{q}_{\mathrm{r} i}=\mathrm{A}_{\mathrm{i}} \alpha_{\mathrm{ri}}\left(\theta_{\mathrm{i}}-\sum_{\mathrm{i}=1}^{8} \mathrm{~g}_{\mathrm{i}} \theta_{\mathrm{j}}\right)
$$

ここで,

$q_{\mathrm{r}} \mathrm{i}$ :ボイド表面節点 $\mathrm{i}(\mathrm{i}=1$ ～8)からの放射熱伝 達量, $\left[\mathrm{H} / \mathrm{m}^{2}\right]$

$\mathrm{A}_{\mathrm{i}}$ : 節点 $\mathrm{i}$ が代表するボイド表面确, $\left[\mathrm{m}^{2}\right]$

$\alpha_{\mathrm{r} i}$ :節点 $\mathrm{i}$ の放射熱伝達率, [ $\left.\mathrm{W} / \mathrm{m}^{2} \circ \mathrm{K}\right]$

$\alpha_{\mathrm{ri}}=\varepsilon \sigma_{\mathrm{b}}\left(\mathrm{T}_{\mathrm{i}}{ }^{3}+\mathrm{T}_{\mathrm{i}}{ }^{2} \mathrm{~T}_{\mathrm{m}}+\mathrm{T}_{\mathrm{i}} \mathrm{T}_{\mathrm{m}}{ }^{2}+\mathrm{T}_{\mathrm{m}}{ }^{3}\right) \cdot(17)$

$\theta_{\mathrm{i}}, \theta_{\mathrm{j}}$ :ボイド表面節点 $\mathrm{i}, \mathrm{j}(\mathrm{j}=1 \sim 8)$ の沮度, $\left[{ }^{\circ} \mathrm{C}\right]$

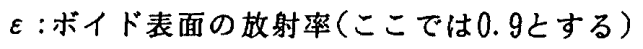

$\sigma_{\mathrm{b}}$ :Stefan-Boltzmann定敨 $\left(=5.67 \times 10^{-8}\left[\mathrm{H} / \mathrm{m}^{2} \circ \mathrm{K}^{4}\right]\right)$

$T_{i}$ :節点 $i$ の絶対温度, [K]

$T_{\mathrm{m}}$ :ボイド表面節点の絶対温度の平均值, [K]

$\mathrm{g}_{\mathrm{i} i}$ :Gebhartの放射吸収係数 ${ }^{6)}$ ，7)

対流䕀伝達率 $\alpha$ cは空調時を強制対流 ${ }^{[4]}$, 空調停止時 を自然对流とした。空調時(強制対流・乱流状態)の対流 熱伝達率 $\alpha$ 。 i は式 $(18)^{8)}$ 及び $(19)^{9)}$ を用いて求めた。

$\alpha_{\mathrm{cti}}=(\lambda / \mathrm{d},)_{\mathrm{Nu}}$

$\alpha_{c \unlhd i}:$ ボイド表面節点 $\mathrm{i}$ の強制対流熱伝達率,

$$
\left[\mathrm{H} / \mathrm{m}^{2} \circ \mathrm{K}\right]
$$

$\lambda:$ 熱伝尊率, $[\mathrm{H} / \mathrm{m} \circ \mathrm{K}]$

$d 。$ : 相当直径(円管の場合直径 $d$ に等しい), [m]

$\mathrm{Nu}$ :Nusselt数

$\mathrm{Nu}=0.022 \mathrm{Re}^{0.8} \mathrm{Pr}^{0.5}$ (Kaysの式)

Re:Reynolds数 Pr:Prandtl瀿 $(=0.69)$

$$
\mathrm{Re}=\nu / \nu
$$

\begin{tabular}{|c|c|c|c|c|c|}
\hline 名 & 空気 & $3 \times \eta \eta-1$ & 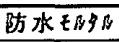 & $87-8$ & 断熱材 \\
\hline $\begin{array}{c}\text { 此熱, } \\
\times 10^{3} \\
{[\mathrm{~J} / \mathrm{kgf} \cdot \mathrm{K}]}\end{array}$ & 1.005 & 0.879 & 0.795 & 0.419 & 4. 480 \\
\hline $\begin{array}{l}\text { 密 } \rho \\
{\left[\mathrm{kgf} / \mathrm{⿴囗十}^{3}\right]}\end{array}$ & 1.20 & 2200 & 2000 & 7800 & 20 \\
\hline 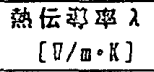 & 0.022 & 1.105 & 1.302 & 44.20 & 0.041 \\
\hline
\end{tabular}

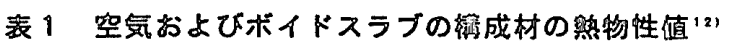

$\nu:$ 動蕗性係数, $\left[\mathrm{m}^{2} / \mathrm{s}\right]$

空調停止時には表面温度とボイド空気温度の差及び熱流 方向を考虑して対流熱伝達率 $\alpha$ cn i を与えた。すなわち

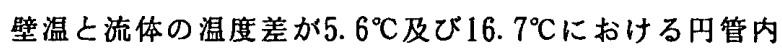
自然対流時の対流熱伝達率 ${ }^{10)}$ を直線補間して $\alpha_{\mathrm{cn} \text { i }}$ の值 を求めた ${ }^{[2] 。 ~}$

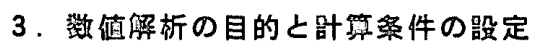

ボイドスラブのボイドを空調ダクトとして用いる場合， ボイドからスラブへの熱栘動によって，ボイドを通過す る空気温度が変化する。中間階の場合には，この熱移動 によってスラブへ吸収・蓄熱された影熱は時間遅れを伴 って室内に放熱されるから，熱収支の面からいえば中間 階のボイドスラブの断熱は不要であるといえる。しかし 中間階でも無断熱のままではスラブ表面に温度むらや結 露が発生する可能性はある。

一方最上階のボイドスラブが無断熱であるとスラブへ 吸収・蓄熱された顕熱のかなりの部分が貫流熱となって 外気に流出する。したがって最上階のボイドスラブにつ いては断熱は不可欠である。

そこでここでは，稫々の断熱を行ったボイドスラブを 空調に利用する場合についてシミュレーションを行い, 以下の钼点から考察を加え，ボイドスラブの断熱に関す る設計資料をまとめることを試みる。

1)中間階におけるスラブ表面の温度分布

2)最上階スラブにおける室内外表面の流出入熱量

3)最上階スラブ室内側表面の吸放熱を考愿しない場合 の供給(除去)熱基の割合

4)最上階スラブ室内側表面の吸放熱を考屁した場合の 供給 (除去) 熱量の割合

5)冷房時の中間階における表面結露発生の可能性 実際の使用条件に近い非定常熱環境を考思してシミュ レーション行うために，以下に示す条件設定を行った。

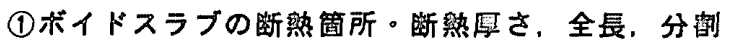
ボイドスラブの断熱箇所はスラブの室内㑡表面, 外気 側表面，ボイド表面の 3 箇所が考えられる。そこで図 7 (a)〜（i）に示す 9 種類の断熱及び無断熱のスラブ断面を 想定した。また，供給空気の温度・熱流変化を調へるた め, 図 5 におけるボイドの全長 L は $20 \mathrm{~m}$, 流れ方向の断面 の間隔 $\Delta \mathrm{L}$ は $1 \mathrm{~m}$ とした。分割数 Nは20となる。 


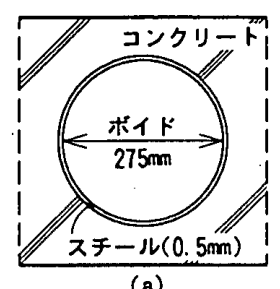

中間陼·無歁热

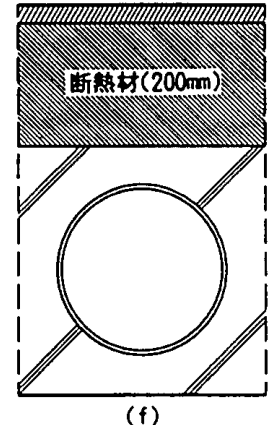

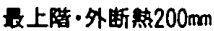

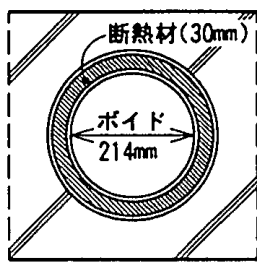

(b)

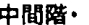

ボイド表面断熱 $30 \mathrm{~mm}$

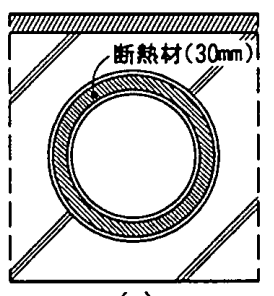

(9)

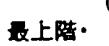

ボイド表面断㥿 $30 \mathrm{~mm}$

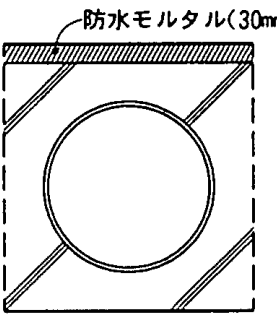

(c)

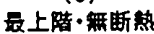

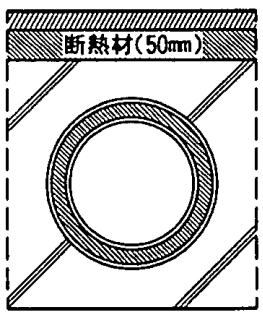

(h)

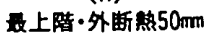

トボイド表面断㷛 $30 \mathrm{~mm}$

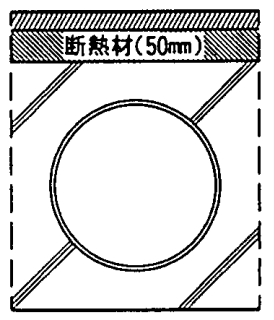

(d)

最上薜·外断熹 $50 \mathrm{~mm}$

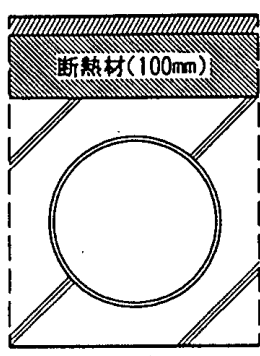

(e)

最上陼·外断热 $100 \mathrm{~mm}$

図 7 計算対象としたボイドスラブの断面

\section{(2)ボイドへの供給空気温度と風量}

ボイドへの供給空気温度の時間変化はスラブ表面の温 度分布や室内外への流出入熱量に影響する。この供給空 気温度と風量は時刻別の室顕熱負荷と室温により決まる。 そこで，典型的な R C 造事務所ビルの 1 フロアにおける 時刻別の熟負荷と室温により，供給空気温度と風量を定 める方法を採る。熱負荷を計算する建物モデルとして， 文献11)のサンプルデータに用いられている事務所ビル （図 6 参照, 所在地: 東京, 主要構造: R C 造, 階高 $3,700 \mathrm{~mm}$, 天井高 $2,600 \mathrm{~mm}$, 外周に幅 $3,700 \mathrm{~mm} \times$ 高さ $1,900 \mathrm{~mm}$ の空が配 置されている)を用いる。また, 室内の温湿度(暖房時 22 ${ }^{\circ} \mathrm{C}, 50 \%$ ，冷房時 $\left.26^{\circ} \mathrm{C}, 50 \%\right)$ や室内使用条件も同サンプ ルデータを利用する。

休や天井に図 5 のようなボイドスラブを用いると，設 定した建物モデルと条件が異なることになるから，熱負 荷も当然変化する。しかし，ここで建物モテルを設定す る目的は一般的な事務所ビルの空調において妥当とみな せる供給空気温度と風量を得ることであるから，特異な 熱負荷でない限りこの目的は達成できよう。そこで用い るボイドスラブ毎にその都度負荷計算は行わず，上記モ テルの熱負荷を一律に用いることにする。

外界条件は，文献11)の東京におけるTAC10\%の設計計 算用気象デー夕を利用する。最上階の場合は同じ気象デ 一夕からスラブの日射昅収率を0.70，長波長放射率を 0.90 として求めた相当外気温度を用いる。

以上のような建物条件, 室内使用条件及び外界条件か ら，中間階と最上階のインテリアゾーンの顕熱・潜熱負 荷を得, この值と室温から時刻別の供給空気温度と風量
表 2 ボイドスラブのケース名とその計算条件

\begin{tabular}{|c|c|c|c|c|c|}
\hline \multirow{2}{*}{ 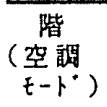 } & \multicolumn{2}{|c|}{ 断熱材厚 [ $\mathrm{mm}]$} & \multirow{2}{*}{$\begin{array}{l}\text { 図 } 7 \\
\text { の断 } \\
\text { 面形 }\end{array}$} & \multirow{2}{*}{$\begin{array}{l}\text { 供給 架 } \\
\text { 気流速 } \\
{[\mathrm{m} / \mathrm{s}]}\end{array}$} & \multirow{2}{*}{ 名 } \\
\hline & 外気側 & ボイド & & & \\
\hline \multirow{2}{*}{$\begin{array}{l}\text { 中間階 } \\
\text { (暧冷 }\end{array}$} & \multirow{2}{*}{0} & \multirow{2}{*}{0} & \multirow{2}{*}{ (a) } & 6.00 & ケース 1 \\
\hline & & & & 3.00 & ケース 2 \\
\hline 房) & 0 & 30 & (b) & 4.96 & ケース 3 \\
\hline \multirow{8}{*}{$\begin{array}{c}\text { 最上階 } \\
\text { (暧冷 } \\
\text { 房) }\end{array}$} & \multirow{2}{*}{0} & \multirow{2}{*}{0} & \multirow{2}{*}{ (c) } & 6.00 & ケース 4 \\
\hline & & & & 3.00 & ケース 5 \\
\hline & 50 & 0 & $(d)$ & 3.00 & ケース 6 \\
\hline & 100 & 0 & (e) & 3.00 & ケース 7 \\
\hline & 200 & 0 & (f) & 3.00 & ケース 8 \\
\hline & 0 & 30 & $(g)$ & 4.96 & ケース 9 \\
\hline & 50 & 30 & $(h)$ & 4.96 & ケ-ス 10 \\
\hline & 100 & 30 & (i) & 4.96 & ケース 11 \\
\hline
\end{tabular}

を決定する。運転方式は定風量式, 空調時間は 8:00 19:00とした。時刻別の顕熱・潜熱負荷を図 8（1）（3） に，供給空気温度の経時変化を図 9 (1)〜（3）に示す。ま た相当外気温度を図 9 (2)(3)に示す。

(3)シュレーションのケース設定

表 2 に示す11のケースについて, 冷暧房時の計算を行 うことにする。ボイド空気の流速は，6.00，3.00,4.96m/s の 3 種類である。最上階において図 1 に示した $400 \mathrm{~mm} ヒ ゚$ ッチのボイドを全て空調に使用し, 冷房最大負荷時の吹

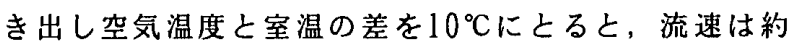
$3.00 \mathrm{~m} / \mathrm{s}$ となる。流速 $6.00 \mathrm{~m} / \mathrm{s}$ は流速 $3.00 \mathrm{~m} / \mathrm{s} に$ 比へて室 温と供給空気温度の差を半分にした場合に同し熱負荷を 処理するための設定である。また $4.96 \mathrm{~m} / \mathrm{s}$ はボイド表面 の断熱によりボイド断面積が減少し, 流速 $3.00 \mathrm{~m} / \mathrm{s}$ のま 


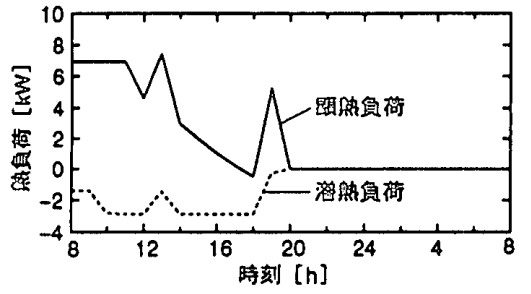

（1）中間階・㖟屏時

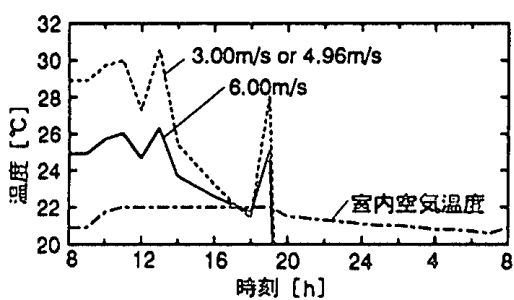

（1）中間階・叒房時

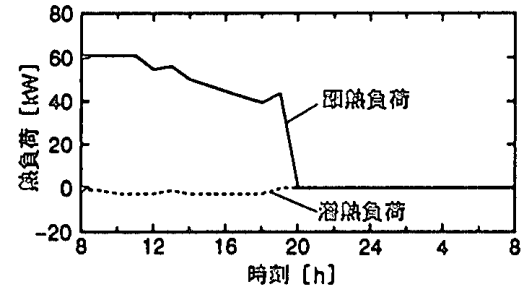

（2）漫上嘴・㱬房時

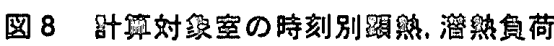

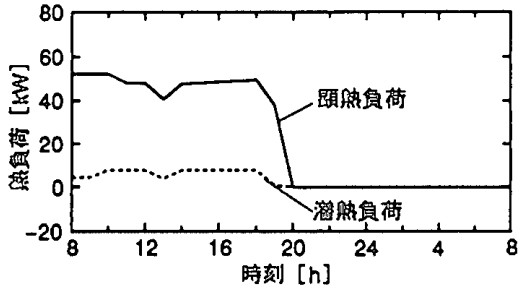

（3）最上階。冷房時

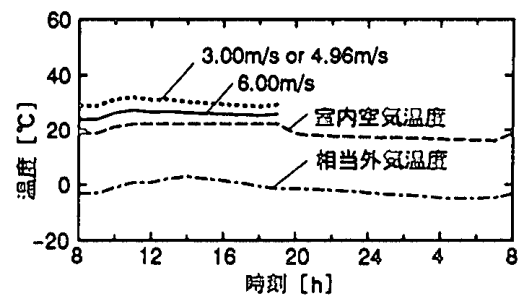

（2）最上階・㖟层的

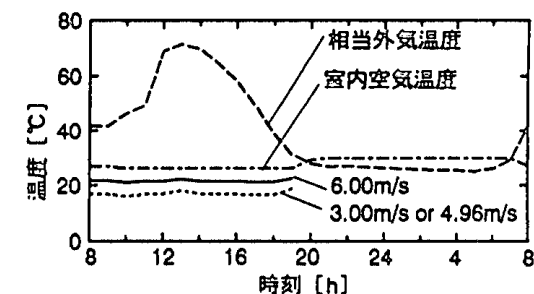

（3）最上隍・冷房時

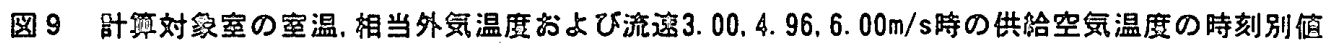

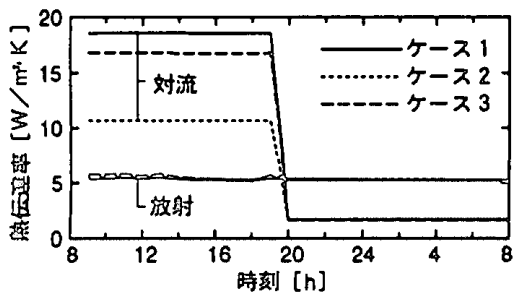

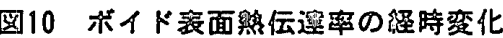
(中間階, $L_{n}=1 \mathrm{~m}$, 图 $4(1)$ の節点(9)

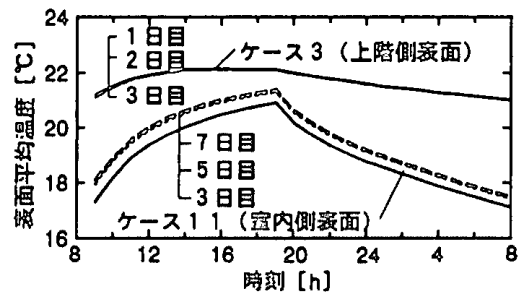

图11㪚房時のスラブ裴面平均温度 の经時血化

(ケース 3 らよびケース11. $\left.L_{n}=10 \mathrm{~m}\right)$

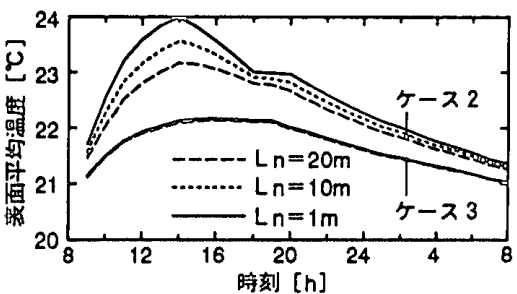

图12 スラブ上階側表面平均温庶と 供路口からの距酷 $\mathrm{L}$ のの閣係 （喓屏時，㢵第7日目）
までは供給風量が減少することを流速で補った場合であ り，供給空気と室温との差は $3.00 \mathrm{~m} / \mathrm{s}$ 時の場合と等しい。 図10はボイド表面の熱伝達率の経時変化の一例を示す。 対流熱伝達率は空調が停止する20時に急激に小さくなる が，それ以外はほほ一定である。また放射㷫伝達率は運 䎐状態の影短を対流熱伝達率ほどは受けていない。ボイ ド表面に断熱を施したケース 3 の空調時の対流熱伝達率 は，風量を 2 倍にしたケース 1 の $6.00 \mathrm{~m} / \mathrm{s}$ 時の値に近い。

\section{4. 周期定常状態の確認}

シミュレーションは周期定常と見なし得るまで計算を 繰り返し，周期定常状態の 1 日を考察の対象とすること にする。計算初日のスラブの初期温度は中間階のスラブ については図 9 に示した時刻別室温の平均值, 最上階の スラブについては時刻別室温と相当外気温度の平均值で ある。図11は中間階のケース 3 と最上階のケース 11 (と もに嗳房時)について, 図 5 に示す供給口からの距離 L n $=10 \mathrm{~m}$ 断面におけるスラブ表面平均温度の経時変化を 示す。図より中間階のケース 3 は2日目でほほ周期定常 に達しているが, 最上階のケース11は周期定常に達する まで5〜7日分の計算が必要であることがわかる。そこで 中間階については3日分, 最上階については7日分の計算
を行い，それそれれ3日目，7日目以降を周期定常状意と見 なすことにした。

\section{5.中間階スラブ表面の温度分布}

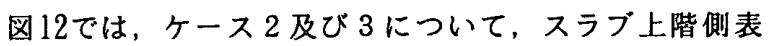
面温度の変化を, 供給口からの距離 $\mathrm{L}_{\mathrm{n}}=1,10,20 \mathrm{~m}$ につい て比較した。ケース2(無断熱)では，14時において L n

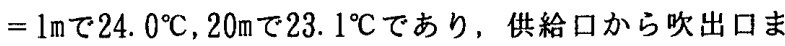
での温度差が約 $0.9^{\circ} \mathrm{C}$ 生じているが，ケース 3 (ボイド表 面30mm断熱)では $\mathrm{L} n$ による温度の差がほとんど生じてい ない。またケース 2 では温度の経時変化が $\mathrm{L}_{\mathrm{n}}=1 \mathrm{~m}$ の場 合で最大約 $2.6^{\circ} \mathrm{C}$ 生じているがケース 3 では約 $1{ }^{\circ} \mathrm{C}$ 䉇囲 に収まっており，中間階ではボイド表面を $30 \mathrm{~mm}$ 程度断熱 することでスラブ表面における流れ方向の温度分布をほ ば均一にできることを示している。

\section{6.记上階スラブにおける断熟方法の険討}

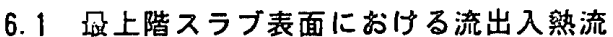

図13は最上階スラブの室内外表面における熱流の経時 変化を示す。図13(1)(2)は無断熱のケース 5 の場合であ る。図中の表面熱流が負の場合はスラブからの流出熱流， 


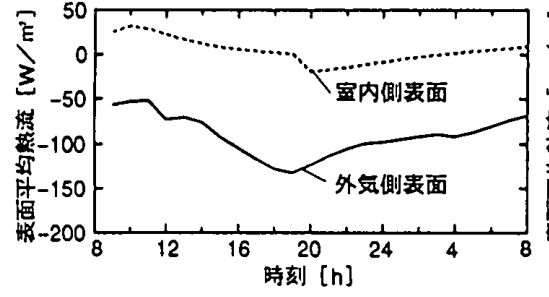

（1）ケース 5 (暖房時)

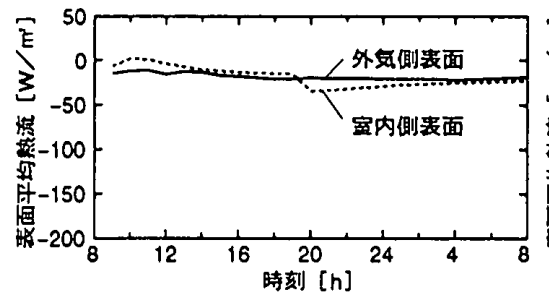

（3）ケース6 (囬房時)

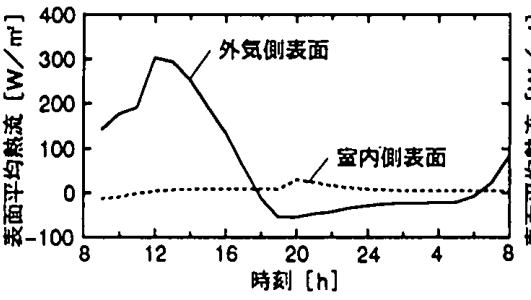

（2）ケース 5 (冷房時)

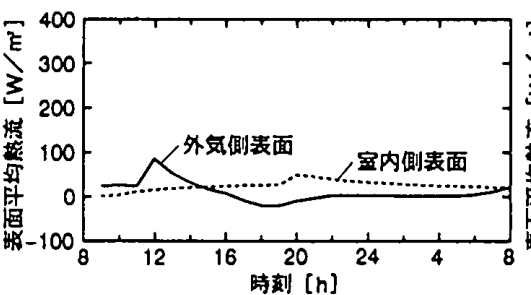

（4）ケース6 (冷房時)

図13最上階スラブの室内外表面における熱流(計累7日目， $L_{n}=10 \mathrm{~m}$ )

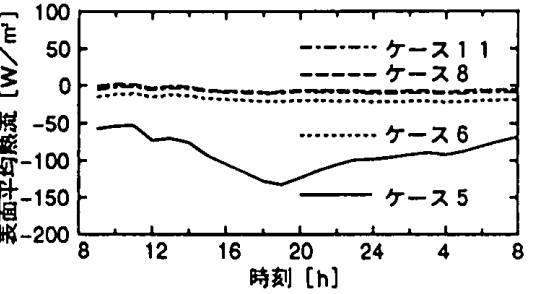

(1) 暖房時

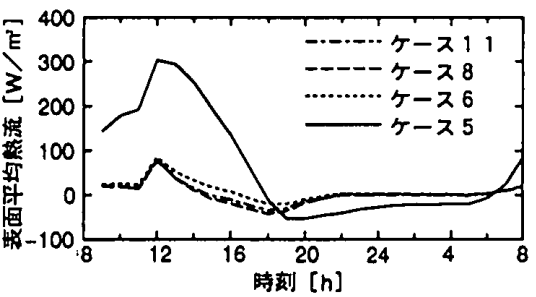

（2）冷房時

图14最上階スラブの外気側表面における 熟流の比较(旪算7日目. $L_{n}=10 \mathrm{~m}$ )

正の場合はスラブへの流入熱流を表す。表面平均熱流の 経時変化は異なるが，いずれも外気側表面の熱流が室内 側表面の熱流を大幅に上回っている。したがって外気に 対する熱の流出入を防ぐためにはスラブの外気側を断熱 する必要がある。図13(3)(4)は外気側表面に厚50mmの断 熱材を貼布したケース6の場合を示す。ケース 5 に比べ 冷暧房時ともに室内側表面の熱流はあまり変化がないが, 外気側表面の熱流が大幅に減少しており，断熱の効果が 表れている。図14は無断熱の場合と外気側表面やボイド 表面を断熱した場合の外気側表面熱流の比較を示す。無 断熱仕様のケース 5 に比へ，有断熱のケースはいずれも スラブ外気側表面の熱流が大幅に低下している。また外 気側表面にのみ厚 $200 \mathrm{~mm}$ の断熱を施したケース 8 と外気 側 $100 \mathrm{~mm}$ ，ボイド表面 $30 \mathrm{~mm}$ の断熱を施したケース 11 では 後者の方が表面熱流がやや少なくなっている。

\section{2 供給熟量の変化に対する予測係数の定義}

ボイドへの供給熱量の一部はスラブへ吸収されるが， 最上階ではその熱量の一部は外気へ流出するから，ボイ ドへの供給熱量のすへてが冷暧房に有効な熱量になると はいえない。断熱の有無や断熱法によってこの有効熱量 はかなり変化するから，効果的な空調を行うためにはス ラブから外気への流出分や室への放熱量を知る必要があ る。この目的のため, 室の空調に寄与する実質的な供給 熱量を次の(1)〜 (4)に定義する係数で表示することにした。 なお定義の説明上暖房時を想定したが, 定義された内容 は(2)の指標を除いて暧房・冷房にかかわらず適用できる。 (1)有効熱量率ETRL n

図 5 の供給ロからボイドへ供給 される熱量のうち，吹出口から室に供給される熱量の割 合を有効熱量率ETR $\mathrm{L}_{\mathrm{n}}$ (Effective Thermal Rate)[\%]と 定義する。ボイドへの調和空気供給口における供給熱量 $\mathrm{Q} 。[\mathrm{~W}]$ と，供給口からの距離が $\mathrm{L} n[\mathrm{~m}]$ の位置につけられ
た吹出口における供給熱量 $\mathrm{Q} \mathrm{Ln}_{\mathrm{n}}[\mathrm{W}]$ は，吹出風量を $\mathrm{V}_{\mathrm{Ln}}$ $\left[\mathrm{m}^{3} / \mathrm{h}\right]$, 供給口, 吹出口の空気温度をそれぞれ $\theta_{0}, \theta_{\mathrm{Ln}}$ $\left[{ }^{\circ} \mathrm{C}\right]$ とすると, 室温 $\theta_{\mathrm{R}}\left[{ }^{\circ} \mathrm{C}\right]$ を基準として次式で表される。

$$
\begin{aligned}
& \mathrm{Q}_{0}=\mathrm{V}_{\mathrm{Ln}} \rho \mathrm{c}\left(\theta_{0}-\theta_{\mathrm{R}}\right) \\
& \mathrm{Q}_{\mathrm{Ln}}=\mathrm{V}_{\mathrm{Ln}} \rho \mathrm{c}\left(\theta_{\mathrm{Ln}_{\mathrm{n}}}-\theta_{\mathrm{R}}\right)
\end{aligned}
$$

$\operatorname{ETR}_{\mathrm{Ln}}$ は次式で表される。

$$
\begin{aligned}
\mathrm{ETR}_{\mathrm{L}_{\mathrm{n}}} & =\mathrm{Q}_{\mathrm{Ln}} / \mathrm{Q}_{0} \times 100 \\
& =\left(\theta_{\mathrm{Ln}}-\theta_{\mathrm{R}}\right) /\left(\theta_{0}-\theta_{\mathrm{R}}\right) \times 100
\end{aligned}
$$

(2)修正有効熟量率ETR $\mathrm{Ln}^{*}$ 修正有効熱量率 $\mathrm{ETR}_{\mathrm{L} \mathrm{n}}{ }^{*}$ (Modified Effective Thermal Rate)[\%]は，供給ロか ら距離 $\mathrm{L}{ }_{\mathrm{n}} \mathrm{m}$ でに室内側表面から室へ流出入する熱量を ETRLnに加味した係数であり，次式で表される。 暧房時:

$\mathrm{ETR}_{\mathrm{L}_{\mathrm{n}}}{ }^{*}=\mathrm{ETRR}_{\mathrm{L}_{\mathrm{n}}}+\left\{\sum_{\mathrm{n}=1}^{\mathrm{Ln}} \mathrm{S} \alpha_{\mathrm{i}}\left(\theta_{\mathrm{s}_{\mathrm{n}}}-\theta_{\mathrm{R}}\right)\right\} / \mathrm{Q}_{0} \times 100 \cdots(25)$ 冷房時:

$\mathrm{ETR}_{\mathrm{Ln}_{\mathrm{n}}}{ }=\mathrm{ETR}_{\mathrm{Ln}}+\left\{\sum_{\mathrm{n}=1}^{\mathrm{Ln}} \mathrm{S} \alpha_{\mathrm{i}}\left(\theta_{\mathrm{R}}-\theta_{\mathrm{s}_{\mathrm{n}}}\right)\right\} / \mathrm{Q}_{0} \times 100 \cdots(2$ ここで,

\section{$\alpha_{\mathrm{i}}$ :室内側表面の総合熱伝達率, $\left[\mathrm{W} / \mathrm{m}^{2} \cdot \mathrm{K}\right]$ \\ $\theta \mathrm{sn}_{\mathrm{n}}:$ スラブ第 $\mathrm{n}$ 断面における室内側表面の温度,}

$\left[{ }^{\circ} \mathrm{C}\right]$

$\mathrm{S}$ : 断面の間隔 $\Delta \mathrm{Lm}$ あたりの室内㑡表面積 $\left(0.4 \mathrm{~m}^{2}\right)$ (3)熟量損失率MTR 熱量損失率MTR(Mean Thermal Loss Rate) $[\% / \mathrm{m}]$ とは，ボイドの単位長さあたりの損失熱 量の割合であり，次式で表される。

$$
M T R=\left(100-\mathrm{ETR}_{20}\right) / 20
$$

MTRにボイド長を乗じれば任意長さのボイドからの熱損 失率 $[\%]$ 得られる。

(4)修正熱量損失率MTR* MTRに対して，スラブの室内 侧表面から室へ流出入する熱量も加味して評価する係数 が，修正熱量損失率MTR* (Modified Mean Thermal Loss Rate) $[\% / \mathrm{m}]$ であり，式(27)のETR 20 をETR $20{ }^{*}$ で置き換 


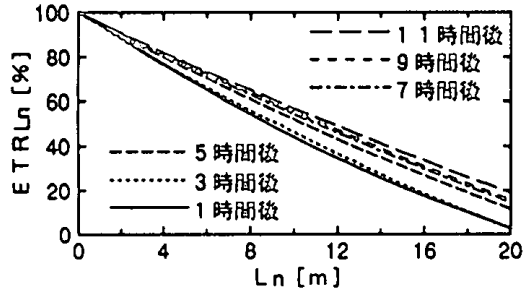

(1) ケース 5

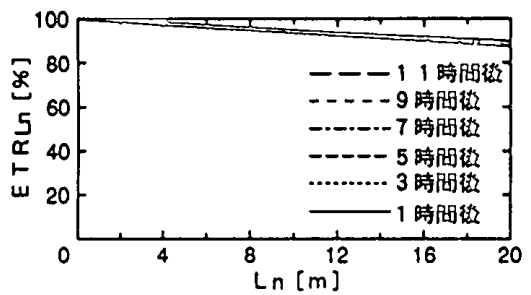

(2) ケース 1

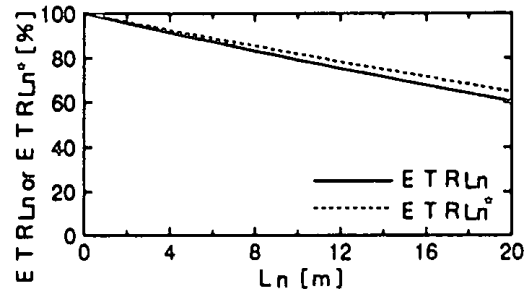

(1) ケース6

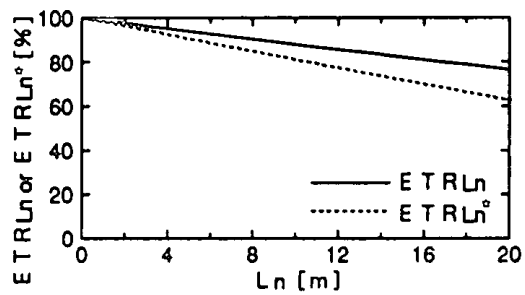

(3) ケース 9

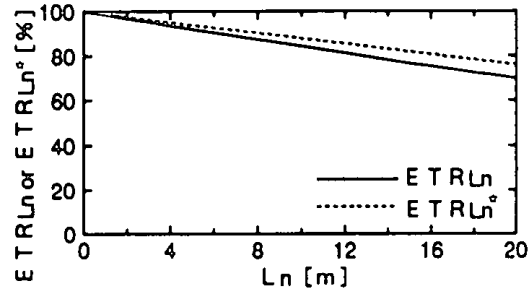

(2) ケース 8

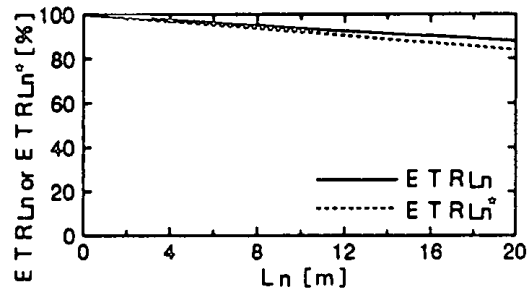

(4) ケース 11

图15 有勃鶖司率ETR

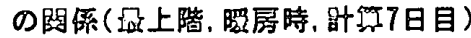

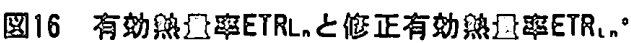

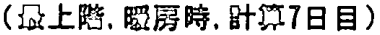

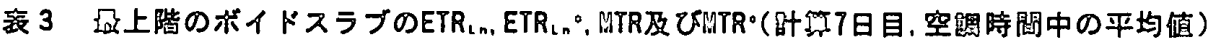
(1) 転屏時

\begin{tabular}{|c|c|c|c|c|c|}
\hline \multirow{3}{*}{ 名 } & \multicolumn{4}{|c|}{$\operatorname{ETR}_{L_{n}}[\%]\left(\operatorname{ETR}_{L_{n}}{ }^{\circ}[\%]\right)$} & \multirow{3}{*}{$\begin{array}{c}\text { MTR } \\
\left(\text { MTR }^{\circ}\right) \\
{[\% / \mathrm{m}}\end{array}$} \\
\hline & \multicolumn{4}{|c|}{ 供給口からの距離 $\mathrm{L}_{\mathrm{n}}$} & \\
\hline & $5 \mathrm{~m}$ & $10 m$ & $15 m$ & $20 \mathrm{~m}$ & \\
\hline ケース 4 & $\begin{array}{r}74.0 \\
(73.0)\end{array}$ & $\begin{array}{r}49.2 \\
(46.9)\end{array}$ & $\begin{array}{c}25.6 \\
(21.5)\end{array}$ & $\begin{array}{c}3.3 \\
(-2.8)\end{array}$ & $\begin{array}{c}4.84 \\
(5.14)\end{array}$ \\
\hline ケース 5 & $\begin{array}{r}74.1 \\
(73.2) \\
\end{array}$ & $\begin{array}{r}50.5 \\
(48.0)\end{array}$ & $(29.5)$ & $\begin{array}{c}9.6 \\
(2.39)\end{array}$ & \\
\hline ケース 6 & $\begin{array}{c}89.3 \\
(90.8)\end{array}$ & $\begin{array}{l}79.1 \\
(81.9)\end{array}$ & $\begin{array}{c}69.6 \\
(73.2)\end{array}$ & $\begin{array}{l}60.5 \\
(64.8)\end{array}$ & $\left(\begin{array}{l}1.98 \\
1.76)\end{array}\right.$ \\
\hline ケース 7 & $\begin{array}{c}90.9 \\
(92.7)\end{array}$ & $\begin{array}{c}82.3 \\
(85.6)\end{array}$ & $(78.7)$ & $\begin{array}{l}66.4 \\
(71.9)\end{array}$ & \\
\hline ケース 8 & $\begin{array}{r}91.9 \\
(93.8) \\
\end{array}$ & $\begin{array}{r}84.2 \\
(87.8)\end{array}$ & $\begin{array}{c}76.8 \\
(81.9)\end{array}$ & $\begin{array}{c}69.8 \\
(76.1)\end{array}$ & $(1.20)$ \\
\hline ケース 9 & $\begin{array}{r}94.0 \\
(90.6)\end{array}$ & $\begin{array}{r}88.0 \\
(81.1)\end{array}$ & $\begin{array}{l}82.1 \\
(71.7)\end{array}$ & $\begin{array}{c}76.5 \\
(62.5)\end{array}$ & $\begin{array}{l}1.18 \\
(1.88)\end{array}$ \\
\hline ケース 10 & $\begin{array}{r}95.7 \\
(94.1)\end{array}$ & $\begin{array}{r}92.8 \\
(90.2)\end{array}$ & $\begin{array}{c}89.4 \\
(85.3)\end{array}$ & $\begin{array}{c}86.0 \\
(80.6)\end{array}$ & $\begin{array}{l}0.70 \\
(0.97)\end{array}$ \\
\hline ケース11 & $\begin{array}{c}96.3 \\
(95.1)\end{array}$ & $\begin{array}{c}93.8 \\
(91.9)\end{array}$ & $\begin{array}{c}90.8 \\
(87.9)\end{array}$ & $\begin{array}{c}87.8 \\
(83.9)\end{array}$ & $(0.61)$ \\
\hline
\end{tabular}

えた次式で表される。

$\mathrm{MTR}^{*}=\left(100-\mathrm{ETR}_{20} 0^{*}\right) / 20$

なお，以降はETR $\mathrm{Ln}_{\mathrm{n}}, \mathrm{ETR}_{\mathrm{Ln}}{ }^{*}$, MTR及びMTR*を空調開始 1 〜 11時間の平均值で扱っている。これは各係效の基準と なるETR $\mathrm{En}_{\mathrm{n}}$ が図15(1)に示すケース5のような無断熱の場 合を除いて，図15(2)のようにほとんど経時変化を生じ ていないからである。各ヶースについて供給口からの距 離 $\mathrm{L}_{\mathrm{n}}=5,10,15,20 \mathrm{~m}$ 位置における $\mathrm{ETR}_{\mathrm{Ln}}, \mathrm{ETR}_{\mathrm{L}_{\mathrm{n}}}{ }^{*}$ とMTR及 びMTR*の一覧を表 3 に示す。なお図1のような円形のボ イドを図 2 のような正 8 角形で近似させるとボイド表面 龧約 $2.6 \%$ 減少するがここれよるETR, ETR*の変化は 最大でも0.6\%であり，近似による影警は工学的に無視 しうる程度であることを確認した。

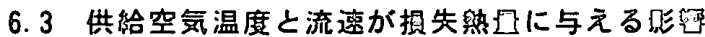

無断熱の場合についてボイドへの供給煠気温度と流速 が損失熱量に与える影㸷を表 3 のMTRとMTR ${ }^{*}$ から考える。 ケース 4 は流速がケース 5 の約 2 倍であるが, 供給空気 温度と室温の差はケース 5 の約半分である。嗳冷房時の
(2)冷房時

\begin{tabular}{|c|c|c|c|c|c|}
\hline \multirow{3}{*}{ 名 } & \multicolumn{4}{|c|}{$\operatorname{ETR}_{L_{n}}[\%]\left(\operatorname{ETR}_{L_{n}}[\%]\right)$} & \multirow{3}{*}{$\begin{array}{c}\text { HTR } \\
\left(\text { HTR }^{*}\right) \\
{[\% / \mathrm{m}]}\end{array}$} \\
\hline & \multicolumn{4}{|c|}{ 供給口からの距離 $\mathrm{L}_{n}$} & \\
\hline & $5 m$ & $10 m$ & $15 m$ & $20 m$ & \\
\hline ケース 4 & $\begin{array}{l}80.3 \\
(83.2)\end{array}$ & $\begin{array}{c}61.8 \\
(67.0)\end{array}$ & $\begin{array}{c}44.5 \\
(51.1)\end{array}$ & $\begin{array}{c}28.3 \\
(35.8)\end{array}$ & $\begin{array}{l}3.59 \\
(3.21)\end{array}$ \\
\hline ケース 5 & $\begin{array}{c}79.6 \\
(81.1) \\
\end{array}$ & $\begin{array}{r}61.3 \\
(63.5) \\
\end{array}$ & $\begin{array}{c}44.8 \\
(47.3) \\
\end{array}$ & $\begin{array}{c}29.9 \\
(32.1)\end{array}$ & $\begin{array}{c}3.51 \\
(3.40)\end{array}$ \\
\hline ケース 6 & $\begin{array}{c}90.4 \\
(93.2)\end{array}$ & $\begin{array}{c}81.4 \\
(86.6)\end{array}$ & $\begin{array}{l}73.0 \\
(80.2)\end{array}$ & $\begin{array}{l}65.1 \\
(74.1)\end{array}$ & $\begin{array}{l}1.75 \\
(1.30)\end{array}$ \\
\hline ケース 7 & & $\begin{array}{l}83.2 \\
(88.8)\end{array}$ & $\begin{array}{c}75.6 \\
(83.5)\end{array}$ & $\begin{array}{c}68.5 \\
(78.3)\end{array}$ & $\begin{array}{l}1.58 \\
(1.09)\end{array}$ \\
\hline ケース 8 & $\begin{array}{l}92.1 \\
(95.1)\end{array}$ & $\begin{array}{r}84.5 \\
(90.3) \\
\end{array}$ & $\begin{array}{c}77.4 \\
(85.6)\end{array}$ & $\begin{array}{l}70.8 \\
(81.1)\end{array}$ & $\begin{array}{l}1.46 \\
(0.95)\end{array}$ \\
\hline ケース 9 & $\begin{array}{r}95.5 \\
(94.2) \\
\end{array}$ & $\begin{array}{c}91.1 \\
(88.3)\end{array}$ & $\begin{array}{c}86.8 \\
(82.6)\end{array}$ & $\begin{array}{l}82.6 \\
(76.9)\end{array}$ & $\begin{array}{l}0.87 \\
(1.16)\end{array}$ \\
\hline ケース10 & $\begin{array}{l}97.1 \\
(96.4)\end{array}$ & $\begin{array}{c}94.3 \\
(92.8) \\
\end{array}$ & $\begin{array}{c}91.5 \\
(89.3)\end{array}$ & $\begin{array}{c}88.8 \\
(85.7)\end{array}$ & $\begin{array}{l}0.56 \\
(0.72)\end{array}$ \\
\hline ケ-ス11 & $\begin{array}{c}97.4 \\
(96.9)\end{array}$ & $\begin{array}{l}94.7 \\
(93.7)\end{array}$ & $\begin{array}{l}92.2 \\
(90.6)\end{array}$ & $\begin{array}{c}89.7 \\
(87.5)\end{array}$ & $\begin{array}{l}0.52 \\
(0.63)\end{array}$ \\
\hline
\end{tabular}

MTR(MTR*)についてみると,いずれもケース4のMTR(MTR*) がケース 5 より高く, ケース 4 の方がボイド損失熱量が 大きいことを示している。しかし両者の差はわずかであ り，供給空気温度と流速が損失熱量に与える影餐は小さ いといえる。なお断熱した場合のボイドについて同様の 計算を行ったが，その場合はこの差がさらに縮まる結果 が得られた。

\section{4 供给照田に与える断熟法の距四}

図16はケース $6,8,9,11$ における暧房時のETR $\mathrm{E}_{\mathrm{n}}$ と $\mathrm{ETR}_{\mathrm{Ln}}{ }^{*}$ を示す。外気側表面を断熱したケース 6 及び 8 の

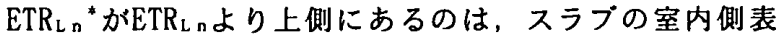
面から室内へ流出する熱流が生じているためである。綖 軸の $100 \% と \mathrm{ETR}_{\mathrm{Ln}}{ }^{*}$ の間はスラブの外気側表面からの流 出分と空調時間中のスラブへの蓄熱分を示す。ボイドの

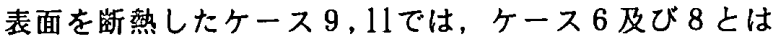
逆に室内からスラブへの熱流が生じているため， ETR $\mathrm{Ln}^{*}$ がETR $\mathrm{L}_{\mathrm{n}}$ を回っている。

スラブ外気側表面とボイド表面の両方を断熱したケー 


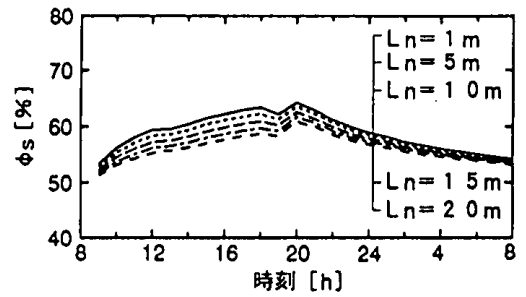

図17 上階㑡表面近傍の相対湿度 $\phi$ s 供給口からの距離 Lnの成係 （ケース2、冷房時）

表 4 スラブ表面における結露検討のための計萛条件

\begin{tabular}{|c|c|c|c|c|c|}
\hline $\begin{array}{c}\text { 階 } \\
(\text { 空調 } \\
\left.⿱ 一-r^{\circ}\right)\end{array}$ & $\begin{array}{l}\text { ボイド } \\
\text { 断熱材 } \\
\text { 厚 [mm] }\end{array}$ & $\begin{array}{l}\text { 图 } 7 \\
\text { の断 } \\
\text { 面形 }\end{array}$ & $\begin{array}{l}\text { 供給案 } \\
\text { 気流速 } \\
{[\mathrm{m} / \mathrm{s}]}\end{array}$ & $\begin{array}{l}\text { 供給口空 } \\
\text { 気温と室 } \\
\text { 温との差 }\end{array}$ & 称 \\
\hline \multirow{5}{*}{$\begin{array}{l}\text { 中間階 } \\
\text { (冷房) }\end{array}$} & \multirow{3}{*}{0} & \multirow{3}{*}{ ( a ) } & 6.00 & $5^{\circ} \mathrm{C}$ & ケース1 \\
\hline & & & 3.00 & $10^{\circ} \mathrm{C}$ & ケース 2 \\
\hline & & & 2.00 & $15^{\circ} \mathrm{C}$ & ケース $2 \mathrm{~L}$ \\
\hline & \multirow{2}{*}{30} & \multirow{2}{*}{ (b) } & 4.96 & $10^{\circ} \mathrm{C}$ & ケース 3 \\
\hline & & & 3.31 & $15^{\circ} \mathrm{C}$ & ケース $3 L$ \\
\hline
\end{tabular}

ス11と，スラブ外気側表面のみを断熱したケース 8 では， 断熱材使用量はヶース11の方が少ないが，両ケースの $\mathrm{ETR}_{\mathrm{Ln}}{ }^{*}$ を比較するとケース11の方が大きい。したがって 断熱効果からみれば，両方を断熱する方が有利である。 ただし図16(2)のように，ケース8ではある程度ふく射 による暖房効果が期待でき，体感的には好ましいという 可能性はある。

表 3 (1)暧房時の各ケースにおけるHTR*を比較する。 まずケース 4 とケース 5 は無断熱の場合であるが, ボイ ドを20m通過した空気はほとんど暖房効果を失っている。 このように最上階で無断熱のボイドスラブを空調に使用 すると，極めて大きな熱損失を伴い現実的でない。

ケース10の MTR*は0.97である。これを断熱量はケース 10より多いが外気側表面のみを断熱したケース 7 のTR* $=1.41$ と比較するとかなり小さい。同様の関係はケース $11\left(\mathrm{MTR}^{*}=0.81\right)$ とケース $8\left(\mathrm{MTR}^{*}=1.20\right)$ につても成立 している。したがってMTR*の比較においてもスラブ外気 側表面だけでなく，ボイドとスラブ外気側表面の両方を 断熱した方が有利という結果が得られる。また，ボイド 内部のみを断熱したケース 9 をみると、 MTR*は1.88であ りケース10の2倍に近く，ケース 9 は断熱不足であると いえよう。

表 3 (2)は冷房時のETR $\mathrm{L}_{\mathrm{n} n}$ *及びMTR*等である。暧房時 と比較するとETR $\mathrm{Ln}^{*}$ が大きく，またMTR*は小さい傾向が あるが，全体的な傾向は暧房時と類似している。

以上の結果から，最上階ではスラブの外気側表面のみ， あるいはボイド表面のみの断熱では外部への熱損失やボ イド空気温度の変化が大きいため，その両方を断熱する ことが有効であるといえる。ボイドを $30 \mathrm{~mm}$ 断熱しスラブ 外気側表面を $50 \mathrm{~mm}$ 断熱すると, 供給空気がボイド長 $20 \mathrm{~m}$
を通過した段階でボイド供給ロでの空気の持つ熱量の80 \%以上が空調に有効である。しかし暖房，冷房ともに $\mathrm{ETR}_{\mathrm{Ln}}{ }^{*}$ の最も高いケース11(ボイド $30 \mathrm{~mm}$ ，スラブ外気側 表面 $100 \mathrm{~mm}$ の断熱)であっても，ボイド長 $20 \mathrm{~m}$ 通過した 段階でそれぞれ83.9\%,87.5\%である。この数值は通常 の空調ダクトと比較すれば決して高い値でなく，図 7 (i) 程度の断熱は最低限必要であると考えられる。

\section{7．中間階スラブにおける表面結露の検討}

ボイドを冷房用のダクトとして用いた場合，スラブの 表面温度が室空気の露点温度以下になると表面結露が生 じる。そこで本節では冷房時の中間階のボイドスラブの 上階側表面, すなわち休表面における冷房時の結露発生 の有無について検討する。表面結露発生の判断には次式 を用いる。

$$
\begin{aligned}
& \phi_{\mathrm{R}}=\mathrm{f} / \mathrm{f}_{\mathrm{R}} \times 100 \\
& \phi_{\mathrm{s}}=\mathrm{f} / \mathrm{f} \mathrm{s}_{\mathrm{s}} \times 100
\end{aligned}
$$

$\phi_{\mathrm{R}}$ : 室空気の相対湿度(冷房時は $50 \%$ に設定), [\%]

$\phi_{\mathrm{s}}:$ スラブ表面(近傍)の相対湿度，[\%]

$\mathrm{f}:$ 室空気の水蒸気圧, [mmHg]

$\mathrm{f}_{\mathrm{R}}$ : 室温に対する飽和水蒸気圧, $[\mathrm{mmHg}]$

$\mathrm{f} \mathrm{s}$ : スラブ上階侧表面の温度に対する飽和水蒸気圧, [mmHg]

式(29)，(30)からfを消去すると，次式となる。

$$
\phi \mathrm{s}=\mathrm{f}_{\mathrm{R}} / \mathrm{f} \mathrm{s}_{\mathrm{S}} \times \phi_{\mathrm{R}}
$$

$\phi$ sが100\%を越える場合は表面結露が生じる。図17では ケース 2 の冷房時について, 式(31)を用いて求めた $\phi \mathrm{s}$ の変化を供給口からの距離 $\mathrm{L}_{\mathrm{n}}$ をパラメータとして表し た。各Lnにおける冷房運転中(8時〜19時)の $\phi$ sは時間 の経過とともに上昇している。このうち $\mathrm{L}_{\mathrm{n}}=\operatorname{lm}$ の場合 の $\phi$ sが他の $\mathrm{L}_{\mathrm{n}}$ の值より高く，結露の危険性が最も高い のはボイドへの空気供給口付近であることがわかる。

図18(1)は最大顕熱負荷時の供給空気温度と室温との

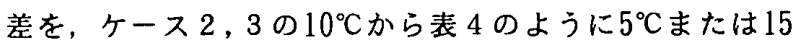
${ }^{\circ} \mathrm{C} に$ 変化させた場合の $\phi_{\mathrm{S}}$ の経時変化 $\left(L_{\mathrm{n}}=1 \mathrm{~m}, \phi_{\mathrm{R}}=50\right.$ \%)を示す。断面形状が同一であれば $\phi$ sは供給空気温度 と室温との差が大きいほど高い。またボイド表面が無断 熱のケース 1，2，2Lの $\phi \mathrm{s}$ は，断熱したケース $3 ， 3 \mathrm{LK}$ 
比へ5〜15\%高い。図18(2)は $\phi_{\mathrm{R}}$ を70\%に想定した場合 の $\phi \mathrm{s}$ の経時変化である。 $\phi_{\mathrm{R}}=50 \%$ の場合(図18(1))に 比へ，各ヶースとも $\phi \mathrm{s}$ が上昇し，最大值は無断熱のケ ース 2 で90\%，ケース 2 Lで95\%となるが, 断熱したケ ース 3，3Lでは $80 \%$ 以下である。

以上より，冷房室の相対湿度が40〜70\%であれば，ボ イド表面が無断熱でボイド空気がかなり低温であっても スラブ表面で結露が生じることはない。しかし実際の空 調室の $\phi_{\mathrm{R}}$ は $70 \%$ を越えている場合もある ${ }^{13)}$ 。また空調 室に開口部の開放など何等かの原因で外気が侵入してき た場合には，結露発生の可能性が考えられる。このよう な場合を考虑するとケース 3 のようにボイド表面を断熱 した方がいといえる。

\section{8.きとめ}

ボイドスラブの伝熱性状を数値解析するため，以下の 計算が可能なコンピュータプログラムを作成した。

(1)有限要素法(FEM)による 2 次元の非定常伝熱解析を用 いてスラブ断面における温度分布とボイドの空気温 度を計算する。さらにボイド空気の流れ方向に緣り 返すことにより，ボイドスラブの 3 次元的な温度分 布を求める。

(2)ボイド内空気の温度や流速による対流熱伝達率の変 化，ボイド表面の相互放射の影餐を考虑する。

このプログラムを用いて，ボイドスラブを一般的な事 務所ビルの空調用ダクトとして用いた場合の, 適切な断 熱法に関するシミュレーションを行った。その結果の概 要は以下の通りである。

（1）中間階の場合, ボイドの表面へ $30 \mathrm{~mm}$ 程度の断熱材を 貼布することでスラブ表面の流れ方向の温度分布を ほほ均一化できる。

（2）最上階の場合，無断熱であると $20 \mathrm{~m}$ 程度で空調効果を 失う。したがって最上階では断熱は必須である。

（3）最上階ではスラブの外気側とボイド表面の両方の断 熱を併用すべきである。

（4）最上階でボイド表面を $30 \mathrm{~mm}$ の断熱としスラブの外気 側の断熱厚を $50 \mathrm{~mm}$ とした場合，20mのボイドを通過し た位置でのスラブの吸放熱を考虑した有効熱量率は $81 \%$ (暖房時)，86\%(冷房時)，スラブの外気侧断熱厚 を $100 \mathrm{~mm}$ とした場合はそれぞれ $84 \%$ (暧房時), $88 \%$ (冷 房時)となる。これらの值は通常の空調ダクトの値と 比較すれば決して高いとはいえない。したがって， 後者程度の断熱は最低限必要であると考えられる。

(5)冷房時の中間階で，室の相対湿度が70\%まで上昇し たとすると，無断熱のボイドスラブ表面での相対湿 度は $95 \%$ 程度まで上昇する場合がある。これに対し てボイド表面を30mm断熱した場合では, 室相対湿度
が70\%でもスラブ表面の $\phi$ sは最大 $80 \%$ 程度に抑えら れる。したがってボイド表面を断熱することにより， 表面結露の危険性が軽減される。

<謝辞 >

本研究における計算及びデー夕処理の方法については 鹿児島大学黒木荘一郎助教授に多くの助言を頂きました。 ここに記して謝意を表します。

\section{本論文に関燠した口頭発蒜}

[1]小原聡司・赤坂裕: 有限要素法による中空スラブの非定常伝熱解 析, 日本建築学会大会梗概集 (懪境工学), pp. 717 718, 1986.8

[2]小原䧔司・赤坂裕他: 有限要䇣法によるボイドスラブの非定常伝 熱解析(その 2 .中空部の相互放射を考宫した堨合の伝熱性状), 日本建築学会九州支部研究報告, 第30号, pp. 125 128, 1988. 3

[3]同上(その 3 .中空部熱伝達率設定の影唒)，日本建築学会大会梗 概集(珢境工学), pp. 505 506, 1988. 10

[4]同上(その 4 . 強制対流時における伝熱性状)，日本建築学会中国 -九州支部研究報告, 第8号, pp. 233 236, 1990. 3

[5]同上(その 5 .強制対流時における伝熱性状), 日本建築学会大会 梗概集(環境工学), pp. 733〜 734, 1990. 10

[6]同上(その6.スラブ内通過時における調和空気の温湿度变化), 日本建築学会九州支部研究報告, 第32号, pp. 121 124, 1991. 3

[7]同上(その 7.スラブ内通過時における調和空気の温度変化), 日 本建築学会大会梗概集(愣境工学), pp. 877 878, 1991.9

\section{参考文献}

1)入江善久:中空スラプのせん断性状に関する研究（その1）一世 ん断応力集中についての考察一，日本建築学会論文報告集， No. 213, pp. $21 \sim 28,1973.11$

2)正木正広・白石裕史・相馬正美:21世紀を住みこなす高性能を狙っ た公団住宅ーボイドスラブの遮音性能一，建築技術，No. 418,19 86.6

3)渡㧅大助・本村翔・井上勝夫・渡部和良: ボイド工法大型スラブの インピーダンス特性に関する基磪的検討, 日本建築学会大会梗概 集(環境工学), pp. 271 272,1991.9

4)矢川元基: 流れと熱伝染の有限要素法入門, 培風館, 1985.9

5)サイバネットシステム, Swanson Analysis Systems:ANSYS Revision 5. 0A, 1994. 3

6)山崎均:多角形の形想係数計算プログラム, 日本建築学会九州支 部研究報告, No. 26 , pp. $41 \sim 44,1982.3$

7)B. Gebhart:A New Method for Calculating Radient Exchanges, ASHRAE Trans., Vol. 65, 1959

8) 日本機珹学会, 伝熱工学㾞料第 4 版, 丸善, pp. 50 58, 1986.10

9) H. H. Rohsenow, J. P. Hartnett, E. N. Ganic: HANDBOOK OF HEAT TRANSFER FUNDAMENTALS, McGram-Hill Book Company, Chapter 7-28. 1985

10)ASHRAE HANDBOOK 1985 FUNDAMENTALS 1985 SI Edition, Chapter23. 4 5

11)HICRO-PEAK/1987 COGEN-DE1利用者マニュアル, 日本コージェ ネレーション研究会, 日本空調設備士協会, pp. 13 28, 1988.1

12)中村洋，小島武男: 現代建築䍜境計画, 才ーム社, pp. 122 126, 1983. 3

13)空気調和衛生工学会繶: 空気調和衛生工学便㹂第11版 II 908, 1987 （1995年 6 月10日原稿受理，1995年11月27日採用決定） 